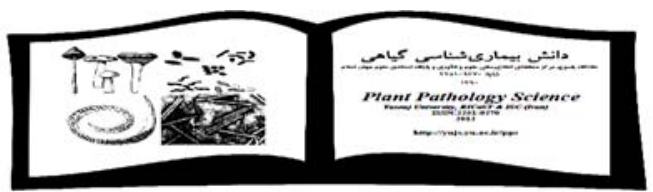

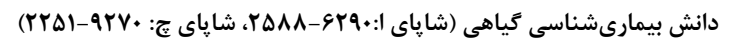

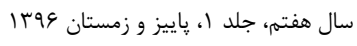

Plant Pathology Science (eISSN:2588-6290, pISSN:2251-9270)

Vol. 7(1), 2018

\title{
Important Criteria for Identification of the Cercospora Species
}

\section{MOUNES BAKHSHI ${ }^{凶}$}

Department of Botany, Iranian Research Institute of Plant Protection, Agricultural Research, Education and Extension Organization (AREEO), Tehran, Iran. ( $\triangle$ : mounesbakhshi@gmail.com) Received: 22.11.2016

Accepted: 30.07 .2017

Bakhshi M. 2018. Important criteria for identification of the Cercospora species. Plant Pathology Science 7(1):1-14.

Abstract: Species of the genus Cercospora are important plant pathogenic fungi with worldwide distribution. They are often associated with leaf spots, occurring on a wide range of hosts in almost all major families of dicots, most monocot families, and even some gymnosperms and ferns. Different characteristics, such as morphology, toxin production and host specificity were used to distinguish species. New research findings have shown that a polyphasic approach, combining morphological, ecological and phylogenetic species concepts, which are discussed in this article, proved the most effective method to distinguish species of the genus Cercospora. Accurate identification of these plant pathogens is the first step to adopt the appropriate management strategies for their disease control. Therefor, it is recommended that, in order to accurate identification of the species of the genus Cercospora, they should be studied and reviewed on the basis of these criteria.

Key words: Sugar beet, Leaf spot, Cercospora

$$
\begin{aligned}
& \text { Cercospora معيارهاى مهمم شناسايى گَونه } \\
& \text { مونس بخشى } \\
& \text { بخش تحقيقات رستنىها، موسسه تحقيقات گياهيزشكى كشور، سازمان تحقيقات، آموزش و ترويج كشاورزى، } \\
& \text { تهران، ايران }
\end{aligned}
$$

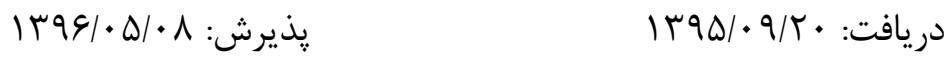

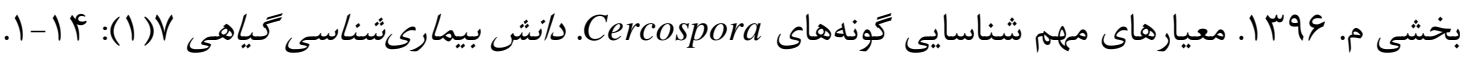

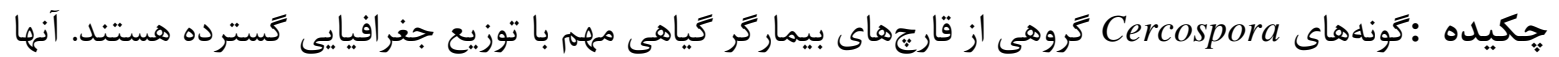

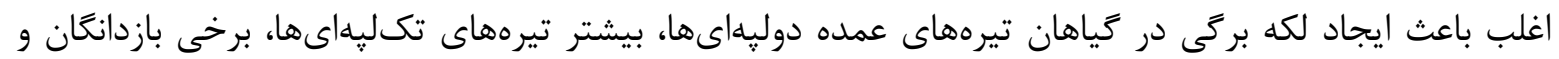

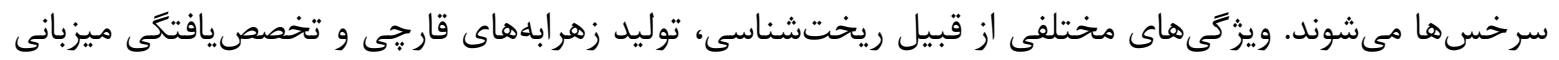

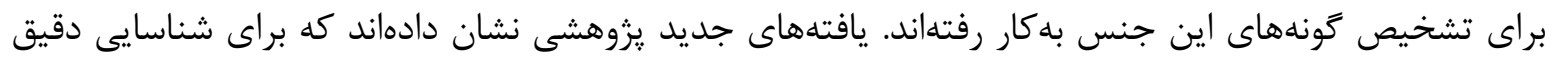

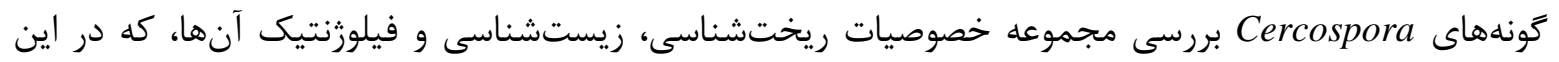

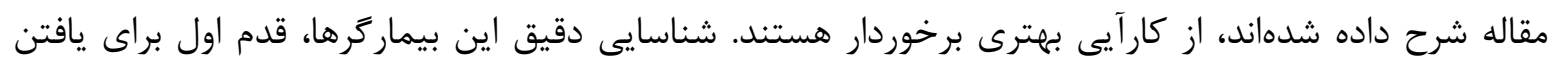

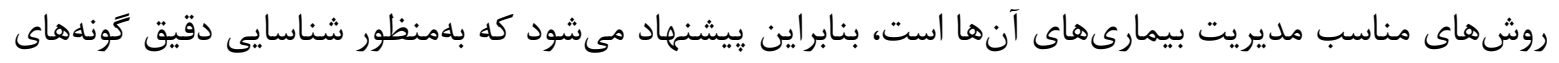

$$
\begin{aligned}
& \text { Cercospora } \\
& \text { وازههاى كليدى: جغندرقند، لكهبرگى، Cercospora } \\
& \text { mounesbakhshi@gmail.com:مسئول مكاتبه }
\end{aligned}
$$


جنس Cercospora اولين بار در سال سع/1 ميلادى توصيف شده است. گونههاى اين جنس در تمامى قارههاى جهان شناسايى شدهاند، اما بيشتر در نواحى گرمسيرى و نيمه گرمسيرى مرطوب شيوع گسترده دارند. آنها بيمارگرهاى مهلم زياهى مىباشند كه باعث از بين رفتن برگها، كاهش سطح فتوسنتز به دليل ايجاد بافتمردگى، خشكى و ريزش زودهنگام برگها، رسيدن زودتر از موعد و كاهش تعداد و اندازه ميوهها مىشوند (Crous et al. 2004, Arzanlou et al. 2007)

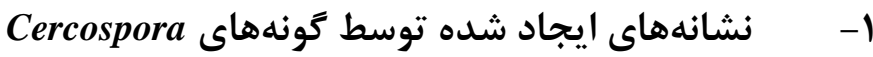

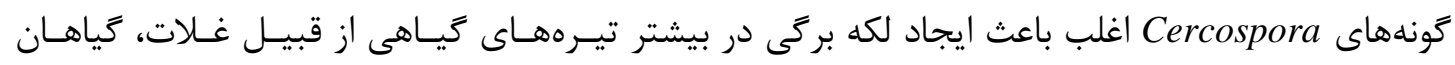

$$
\text { جاليزى و زينتى، درختان جنكلى و جمن مىشوند (شكل () كه از اين بين مىتوان به بيمارىهاى لكه بركى }
$$
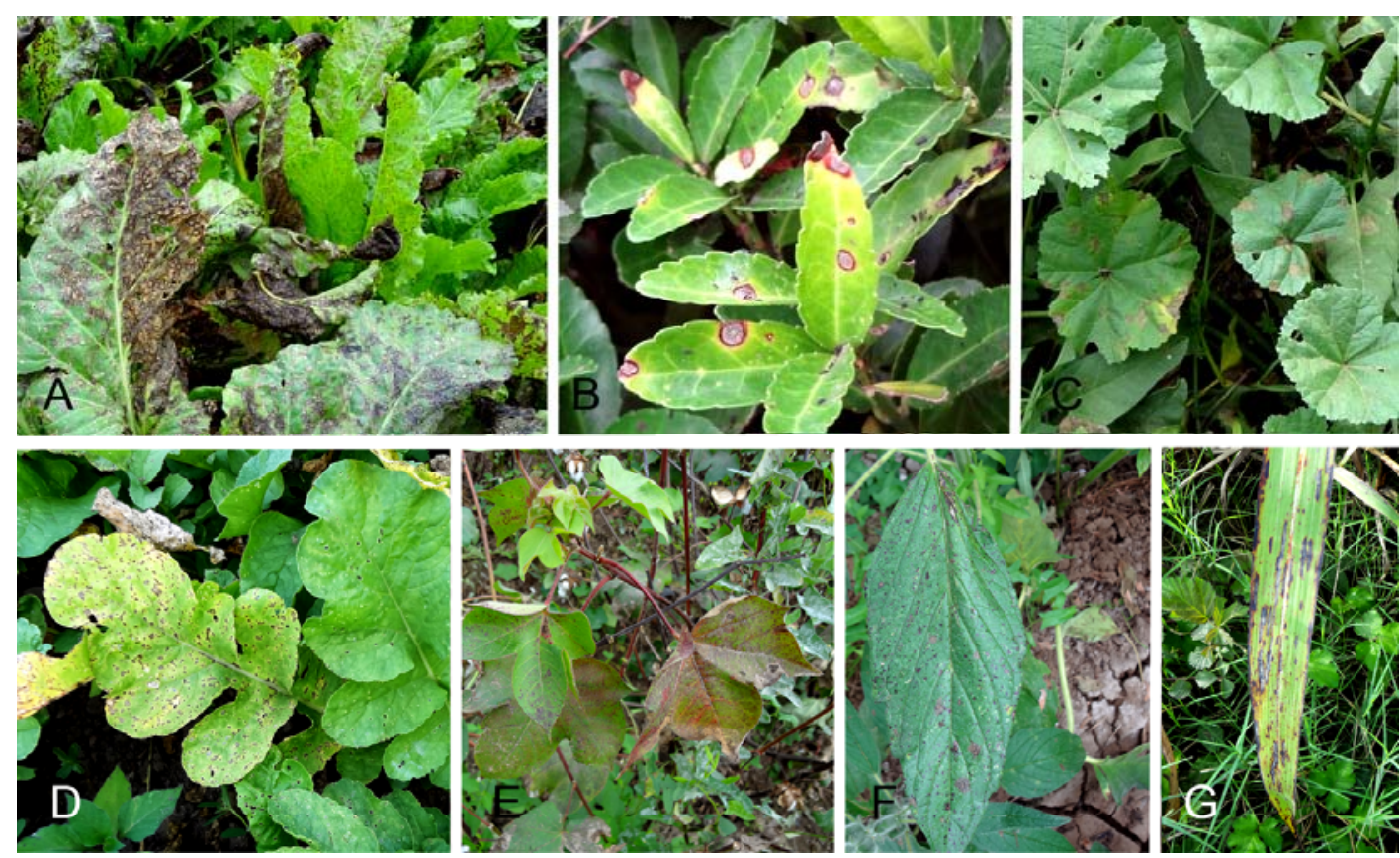

شكل ا- نشانهای لكه بركى ناشى از گونهاى مختلف جنس Cercospora روى گياهان مختلف: A. جغندرقند،

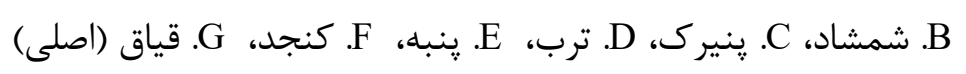

Figure 1. Leaf spot symptoms of Cercospora spp. on different host plants: A. Beta vulgaris, B. Buxus microphylla, C. Malva sp., D. Raphanus sativus, E. Gossypium herbaceum, F. Sesamum indicum, G. Sorghum halepense. 
كرفس (Cercospora apii Fresen. (Groenewald et al. 2006a)، جغندرقند (C. beticola Sacc) (C) (Geiland)

C. zeae-maydis Tehon and (et al. 2001 و Daniels اين محصولات در سرتاسر دنيا وارد مى كنند. با اين حال برخى از گونههاى اين جنس از زخمهاى نكروزه در كلها، ميوهها و بذرها يا يوسيدگى بعد از برداشت ميوهها نيز در سرتاسر دنيا گزارش شدهاند (Silva and Pereira 2008). برخى از گونهها بهعنوان عوامل مهار زيستى علفهاى هرز از قبيل گونه C. caricis Dearn. and House روى علف هرز اويارسلام (Cyperus rotundus L. و كونه C. rodmanii Conway) روى سنبل آبى ( Eichhornia crassipes (Mart.) Solms شده توسط گونههاى Cercospora اغلب برگها را تحت تأثير قرار داده و اغلب اين لكهها بهسرعت گسترشيافته و لكههاى مجاور به هم متصل مىشوند و باعث سوختخى برى مىشوند، و تحت شرايط مرطوب، كنيديومبرها و كنيديومهاى قارج در مركز لكهها تشكيل مىشوند.

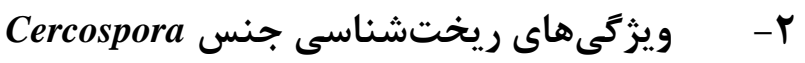

ميسليوم رنكى گَونههاى Cercospora اغلب فرورفته در بافت ميزبان، داراى استروما، كنيديومبرها متمايز از

ريسه رويشى، قهوهاى كمرنت تا قهوهاى، صاف، ساده يا بهندرت منشعب، مستقيمى تـا خميـده، كَاهى زانـويى كـهـ

بهصورت منفرد يا دستهاى (Fascicles) كم تراكم تا متراكم تشكيل مىشوند، سلولهاى كنيديومزا انتهـايى، بـين

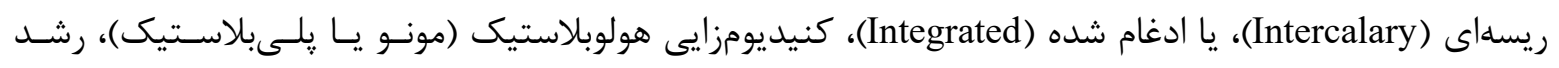
سيميوديال، شيوه جداشدن كنيـديوم از نــوع شـيزوليتيك، محـلـهـاى كنيـديومزايسى مشـخص، ضـخيم، رنتخى،

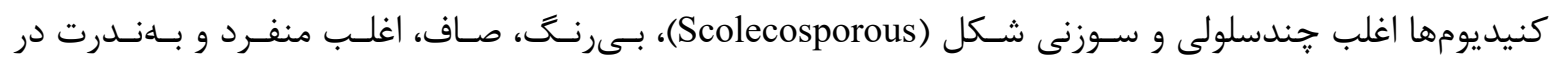
زنجيرهاى آكرويتال تشكيل مىشوند ( Ellis 1971) (شكل ؟).

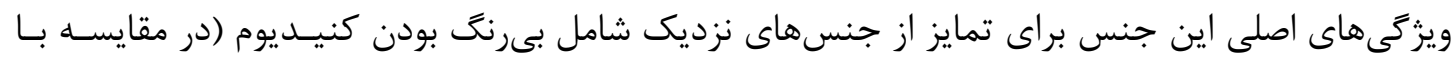
جنس Passalora Fra)، مشخص، ضخيم و رنكى بودن ساختار سلول كنيديومزا و هيلوم (Hilum) در كنيديومها 

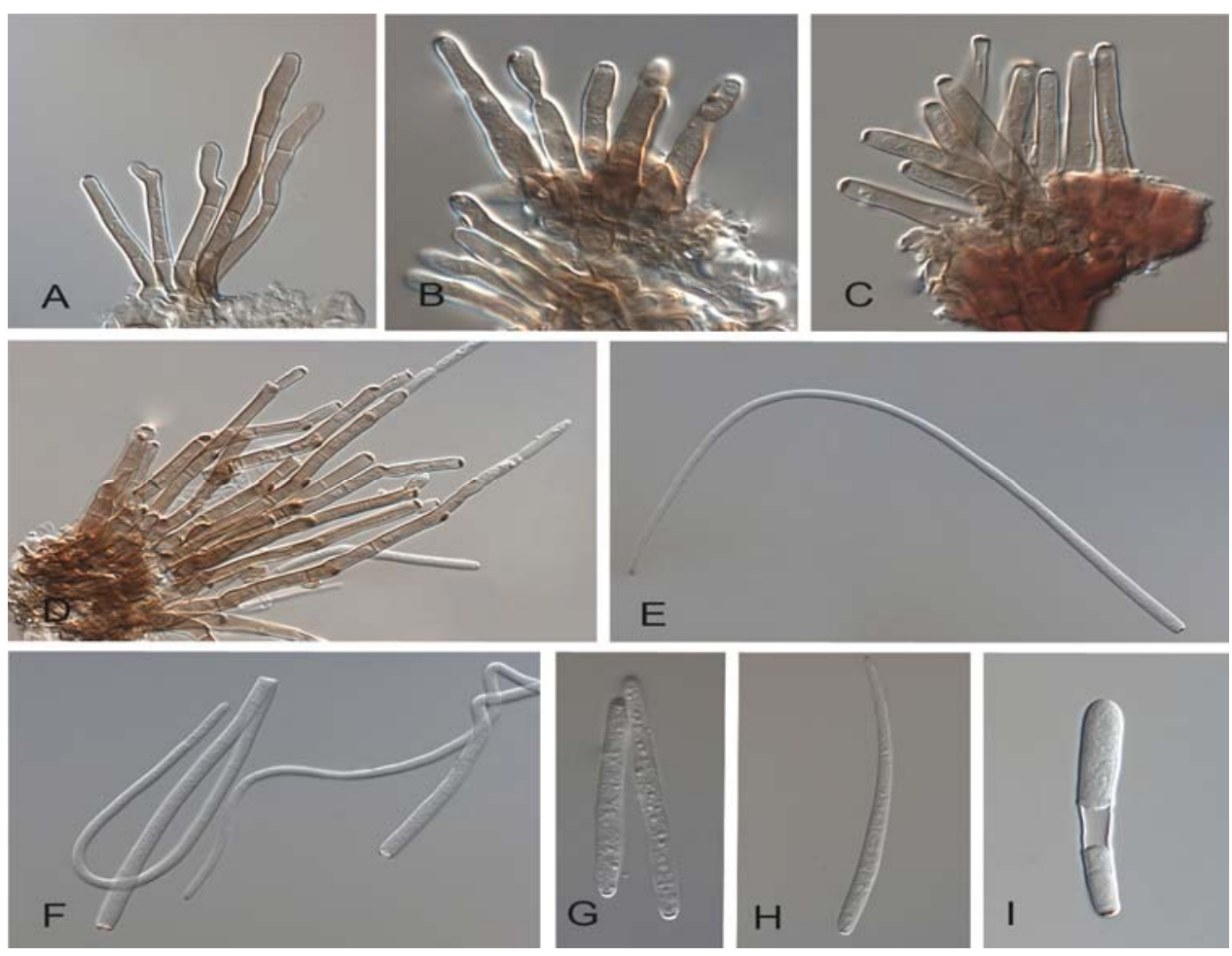

شكل r - A-D: انواع كنيديومبر، E-I: انواع كنيديوم در گونهاى مختلف Cercospora (اصلى)

Figure 2. A-D: Different types of conidiophores, E-I: Conidia of Cercospora spp.

(در مقابل جنس .Pseudocercospora Speg) و صاف بودن سطح ساختارها (در مقابل .Stenella Syd) مىباشند

.(Crous and Braun 2003)

\section{r- - وضعيت جنس Cercospora در سيستم نامخذارى جديد قارجها}

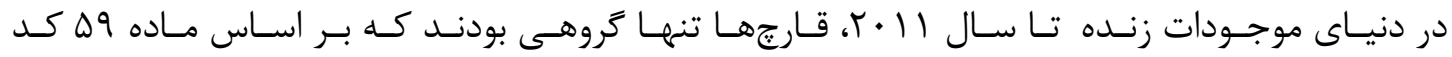

بـين الملــى نـامخـذارى كياهـان (International Code of Botanical Nomenclature = ICBN) اجـازه

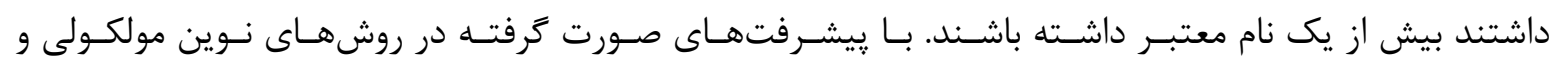
با توجه به اينكه، با در اختيار داشتن تـوالى يـك قـارج بـهراحتـى مسى تـوان جايخـاه آرايسهبنـدى آن را مشـخص نمود و نيازى به داشـتن شـكل جنسـى قـارج بـراى تثبيـت موقعيـت آرايـهبنـدى نيسـت، در خنـــ سـال اخيـر

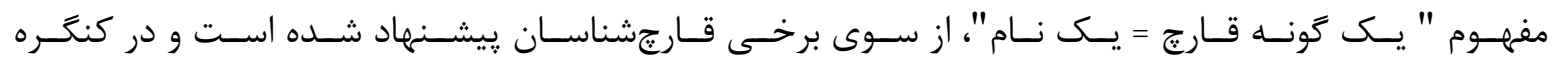




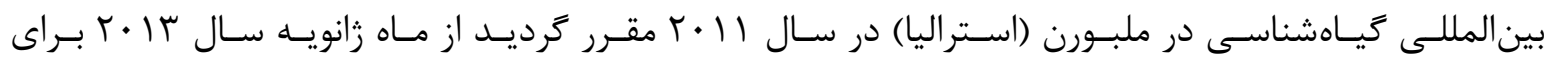
هـر قـارع فقـط يـك اسـم معتبـر وجـود داشـته باشـد (Hawksworth et al. 2011, Kirk et al. 2013). بـر

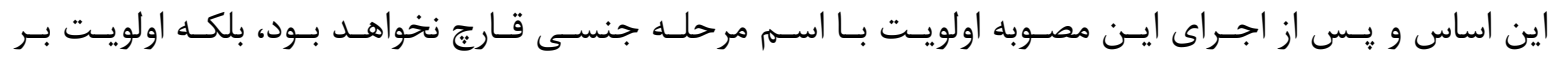

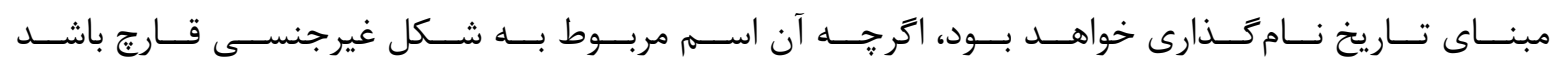

جنس Cercospora با توجه به اينكه مرحله جنسى بيشتر گَونهاى آن ناشناخته است، در كذشته بهعنوان شبه جنس قارجى مطرح بود. در سالهاى اخير با ييشرفتهاى ايجاد شده در تكنيكهاى مولكولى، دادهاى توالى از نواحى رمزگذار و فاقد رمز زنوم براى بررسـى روابـط فيلـوزنتيكى بـين گَروههـــ مختلـف قـارجى در سـطوح آرايهبندى مختلف بهكار رفتهاند. در اين بين دادههاى حاصـل از تـوالىيـابى جنـدرنى، جـنس Cercospora را در دودمان Mycosphaerella قرار مىدهد (Crous et al. 2009). تا قبل از تصويب قوانين نام كذارى جديد تحت كـد بين المللى نام كذارى جلبك ها، قارجهـا و كياهـان (ICN)، جــس Mycosphaerella Johanson متعلـق بــ تيــــ Mycosphaerellaceae يكى از بزركترين جنسهاى Ascomycota حساب مى آمد كه با شبهجنسهاى آنامورف بسيارى از جمله Cercospora مرتبط بود (Crous et al. 2004, Groenewald et al. 2013). اين جنس در مفهوم گسترده (Mycosphaerella sensu lato) شامل حدود . ... نام و همراه با آنامورفهاى آن بيش از . . . . كونه را در بر مى گرفت (Arzanlou et al. 2007, Crous et al. 2009). با توجه به تعداد بسيار زياد جنسهاى آنـامورف، افزودن اطلاعات توالىيابى زنتيكى مشخص نموده است كه اين جنس جند نيايى است، بنابراين به جندين جـنس تفكيك شده است (Crous et al. 2009). بنابراين، Mycosphaerella sensu stricto محدود به آرايههاى بـا شـكل غيرجنسى Ramularia Unger شده است (Groenewald et al. 2013). بنابراين جـنس Cercospora هـم اينـى بهنوان يك جنس مستقل در تيره Mycosphaerellaceae مورد تأييد است (Kirk et al. 2013$).$

\section{Cercospora مرورى بر تاريخجه شناسايى كَونه}

معيارهاى شناسايى گونههاى Cercospora، از زمان توصيف اين جنس دستخوش تغيير بسيارى شدهاند. 
در طى ساليان متمادى، ويزَّى هاى مختلفى از قبيل ريختشناسى، توليد زهرابههـاى قـارجى و تخصـص يـافتخى ميزبانى براى تمايز گونههاى اين جنس بهكار رفتهاند كه در اين قسمت مورد بحث قرار مى گيرند.

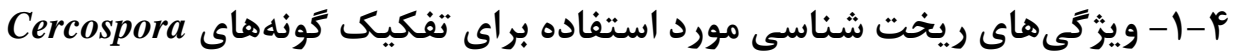

ويزگى هاى ريختشناسى مورد استفاده در تفكيك گَونههـاى جــس Cercospora، شـامل شـكل و انـدازه

كنيديوم، حضور يا عدم حضور ميسليوم ثانوى و ويزگگىهاى ريختشناسى كنيديومبر بـودهانـد كـه متأسـفانه ايسن

Groenewald et ) مشخصات تنوع درون گونهاى بسيارى را نشان مىدهند كه استفاده از آنها را مشكلساز مى كند al. 2006bb و از طرف ديخر شناسايى گونهها بر اساس خصوصيات ريختى نياز به دانش تخصصى دارد. يكى ديخـر از مشكلات مرتبط با شناسايى گونههاى اين جنس بـر اسـاس صـفات ريخـتشناسى، نـرخ رشــ يـايين و عـدم هاگزايى آنها روى محيطهاى كشت مصنوعى مىباشد.

بيشتر گَونهاى جنس Cercospora توليد زهرابه قارجى به نام سركوسيورين مىنمايند. در ابتدا تصـور بـر اين بود كه اين زهرابه تنها توسط گونههاى حقيقى Cercospora توليد مىشود و گونههايى كه اين زهرابه را توليد نمى كنند، متعلق به وابستكان جنس Cercospora مىباشند. با اين حال هرجند اين تركيب ممكن است بيمـارىزايى را افزايش دهد، اما عامل اساسى بيمارىزايى بهحساب نمىى آيد، زيرا بلوسيله تمام گونـههــا توليـد نمسىشـود (Groenewald et al. 2006a) تحت تأثير شرايط محيطى و زنتيكى قرار دارد (Groenewald et al. 2006a)؛ بنابراين با توجه به بىثباتى در توليد اين زهرابه و ميزان آن، كاربرد اين ويزگى نيز در تفكيك گونهاى اين جنس مؤثر واقع نشد.

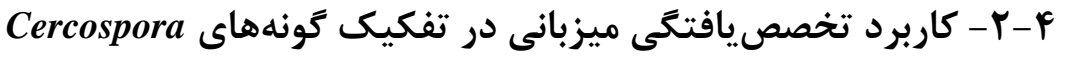

تخصصيافتخى ميزبانى از ديرباز بهعنوان يك معيـار عمـده بــراى تفكيـك گونـههـــ جـنس Cercospora از

همديكر به كار رفته است. بهطورى كه در صورت جداسازى يك گونه Cercospora از يك ميزبان متفاوت، بهعنوان گ گنه جديد در نظر گرفته مىشد (Chupp 1954). برخى محققين اظهار كردند كه بيشتر جدايههاى غيرقابل تمايز از نظر خصوصيات ريختشناسى جنس Cercospora متعلق به گَونه apii مي باشند كه روى دامنه كسـتردهاى 
از ميزبانها حضور دارد (Groenewald et al. 2006a). اين نكرش در تكنگارهى گونههاى Cercospora كه در آن

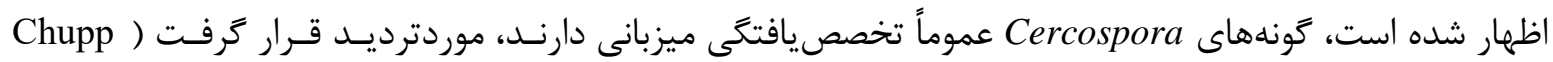

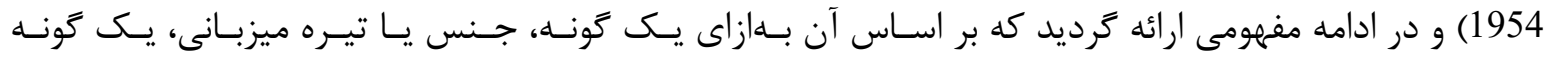
Cercospora وجود دارد (Chupp 1954). اين مفهوم منجر به توصيف تعداد بـشمارى گونه بر اساس ميزبان شـــ و بيش از · ․ . نام براى آن ليست شد (Pollack 1987). با اين حال، مشكل مههم در رابطه با آرايسهبنـدى جـنس Cercospora درجه تخصصيافتخى ميزبانى گونههاى مختلف است. قابليت آلوده كـردن ميزبـانهـاى مختلـف در آزمايشهاى مايهزنى، از ارزش بسيارى در تعيين حدود گونه برخوردار است. آزمايشهاى مايهزنسى مختلـف نشـان C. beticola تنها با اتكا به ميزبان معيار مناسبى نيست. بهعنوان مثال Cercospora دادهاند كه شناسايى گونههاى مى تواند كافشه (Carthamus tinctorius L) را نيز در طى مايهزنى مصنوعى آلوده كنــ (Lartey et al. 2005). از طرفى، برخى گونهها از قبيل C. canescens Ellis and Martin ،C. apii و Cebrina Pass. Crous and Braun 2003, ) كه در تيرههاى ميزبانى مختلف آلودگى ايجاد مى كنند و دامنه ميزبانى گسترده دارند Lartey et al. 2005, Bakhshi et al. 2012b, Groenewald et al. 2013 تنها با اتكا به ميزبان معرفى شدهاند، با شك و ترديد همراه است.

\section{Cercospora توليدمثل جنسى در كونهای - F}

C. apii علىرغم انتشار گَسترده، تاكنون هيج شكل توليد مثل جنسى براى گونههاى متعلـق بـه مجموعــ

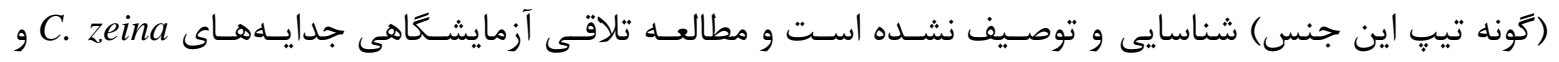
C. zeae-maydis جدايههاى Ceticola با تيبٍاى آميزشى متفاوت در شرايط آزمايشگاه نيز موفقيتى به همراه نداشت (بخشى و همكاران اوج الف). مطالعات انجام گرفته روى ساختار زنتيكى جمعيتهاى برخى گَونهاى جنس Cercospora Weiland et al. 2001, Moretti et ) نشان مىدهد كه تنوع زنتيكى زيادى در بين اعضاى اين كونهها وجـود دارد 2004 .al). در واقع تنوع زنتيكى در بين جمعيتهاى گونههايى كه داراى جرخه جنسى هستند، بلمراتب بيشتر از 
تنوع زنتيكى جمعيـتهــاى همسـانهاى مسىباشـد (Groenewald et al. 2006b). از طرفى تنـوع بـالايى از نظـر ريختشناسى يرگنه از قبيل نرخ رشد، رنغ ميسليوم، ريختشناسى هاگها و توليـد فيتوتوكسـين در گونـههـاى مختلف جنس Cercospora مشاهده شده است (Moretti et al. 2004). محققين در تلاشى براى يافتن منبع ايسن تنوع و تعيين سطح تمايز زنتيكى، امكان وجود جرخه جنسى ينهان در اين قارج را مطرح كردنـد ( Groenewald .(et al. 2006b

در سلسله قارجها، توليدمثل جنسى بلوسيله يك ناحيه خاص زنومى تحـت عنـوان مكـانهـاى زنسى تيـٍ

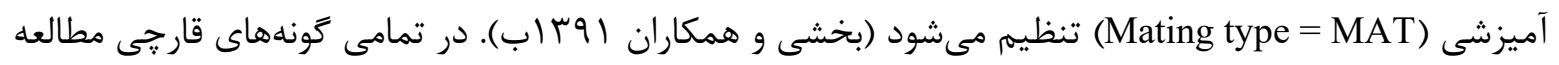
شده تاكنون زنهاى تيب آميزشى شناسايى شدهاند، و قارجهاى غيرجنسى (ميتوسيوريك) نيز در رنوم خود حاوى Coppin et ) زنهاى تيب آميزشى مىباشند و اين زنها در آزمونهاى انتقال زن از كارايى لازم برخوردار هسـتند al. 1997, Linde et al. 2003 .al. حضور زنهاى تيب آميزشى جهت اثبات حضور مرحله جنسى كافى نيست، با اين حال در صورتى كه انتخاب وابسته به فراوانى (در صورت وقوع نوتركيبى جنسى) در اين زنهـاى فـراهم باشـد، آن وقت آللهاى تيڤهاى آميزشى از فراوانى مساوى برخوردار خواهند بود (بخشى و همكاران اqجالـف، اqجاب).

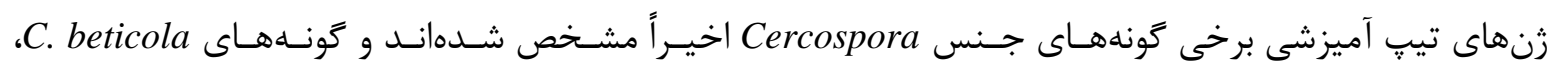
و C. apii هتروتال هستند، با اين وجود تنهـا يـك تيسِ آميزشى در جمعيـتهــاى C. zeina gea-maydis C. apiicola Groenew., Crous and U. Braun يزوهشى، توزيع زنهاى تيڤ آميزشى كونه C. beticola در مـزارع جغندرقنـد در سـطح لكـه، بـرى و مزرعـه در

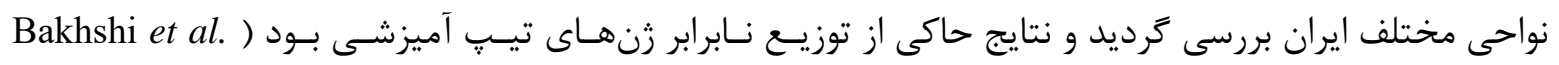
2011). با اينحال دو تيت آميزشى C. beticola با نسبت تقريباً برابر در برخى جمعيتهاى بررسى شـده در سـاير نقاط جهان حضور دارند (Bolton et al. 2012). اين امر نشان مى دهد اين زنهـا ممكـن اسـت در برخسى منـاطق فعال باشند و حاكى از توليدمثل جنسى ينهان است. كشف مرحله جنسى كونههـاى جـنس Cercospora، كمـى 
شايانى در بهبود درك ما از موقعيت آرايهبندى اين جنس خواهد كرد و مشـكلات هويست كونسه در ايسن جـنس را مرتفع خواهد نمود.

\section{Cercospora روش هاى مولكولى براى آرايدبندى كونههاى F-F}

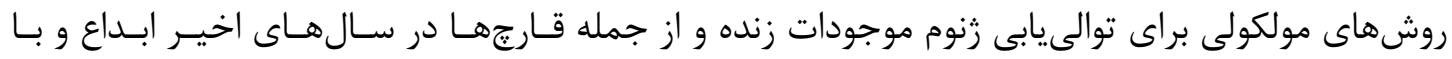
ييشرفتهاى جشمغيرى داشتهاند. با توجه به محدوديتهاى موجود در آرايهبندى ريختشناسى و كاربرد مفـاهيم زيستشناسى كَونه، روشهاى مولكولى به دليل اين كه در مقايسه بـا روشهـاى ســنى از سـرعت عمـل و دقـت بالاترى برخوردار مىباشند، جايعاه خاصى در آرايهبندى و شناسايى گونههاى Cercospora ييدا كردهاند.

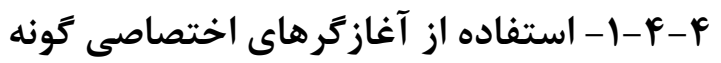

آغازگرهاى اختصاصى طراحى شده بر اساس نواحى مختلف زنوم، بهصورت رايج جهت شناسايى گونسهــاى مختلف قارجى از كشتهاى خالص و از بافتهاى گياهى آلوده با استفاده از روشهاى مبتنى بر واكنش زنجيـرهاى يلى مراز (PCR) به كار گرفته شدهاند (Arzanlou et al. 2007). با طراحى آغازگرهاى اختصاصى بر اسـاس تـوالى زن آكتين (ACT)، محققين توانستند گونه C. beticola را از بافتهاى برگى آلوده جغندرقند تشخيص و رديـابى نمايند (Lartey et al. 2005). در اين راستا، با استفاده از PCR و به كار گيرى آغازگرهـاى اختصاصسى مبتنـى بـر توالى زن كالمودولين (CAL)، شواهد اوليه از وجود گَونهاى متمايز در داخل مجموعه C. apii نيـز ارائـه گرديـد (Groenewald et al. 2005). با اين حال كارايى آغازگرهاى اختصاصسى بـراى اسـتفاده در مقيـاس گسـترده روى جدايههاى بهدستآمده از ميزبانها و مناطق مختلف، مناسب نيست، زيرا هميوشانى معنى دارى در بـين گونسههـا ديده مىشود و براى تشخيص دقيق همه گَونها قابل استفاده نيست. بهعنوان مثال آغازگرهاى طراحى شده بـراى ثن آكتين (Cartey et al. 2005)، بر اساس كونه C. beticola، كونهاى Cercospora به دسـت آمـده از سـاير ميزبانها را نيز تكثير مى كنند (بخشى و همكاران rar (). 


\section{DNA روشهاى مبتنى بر توالى يابى - F-F}

امروزه استفاده از توالىيابى نوكلئوتيدى يا به عبارتى مفهوم فيلوزنتيك كونسه، امـرى رايـج در آرايـهبنـدى قارجهاى بيماركر زياهى است. در حالت كلى استفاده از مفهوم فيلوزنتيـك گونـه، تغيير يـذيرى كمتـرى داشـته و واقعى تر است و تفاوتهاى ريختشناسى نيز عموماً از نهادينه شدن تغييرات در توالىهاى نوكلئوتيدى منشأ مسىگيرند و بنابراين مشكلات مربوط به مفاهيم ريختشناسى و زيستشناسى گونه را مرتفع مىسازد. بررسى روابـط

C. فيلوزنى بين گونه Cercospora و ساير گَونه نزديك مشخص كرد كه جدايههاى متعلق به C. beticola

C. C. apii و C. beticola و C. apii apiicola beticola دادهها مشخص شد كه مفهومى كه گونههاى Cercospora , محدود به جــسـهـا يـا تيـرههـاى ميزبـانى خـاص مىدانست (Chupp 1954)، بهطور كامل نادرست نيست.

جامعترين مطالعه مولكولى با استفاده از توالىهاى جنــدزنى، در زمينـه آرايـهبنـدى جــس Cercospora، يزوهشى است كه در آن با استفاده از دادهاى توالى ينج ناحيـه زنسى (CAL،ACT،TEF1-a،ITS و HIS) روابـط خويشاوندى بين گونههاى اين جنس مـورد مطالعـه قـرار كرفتـهـ اسـت (Groenewald et al. 2013)، مهـمتـرين

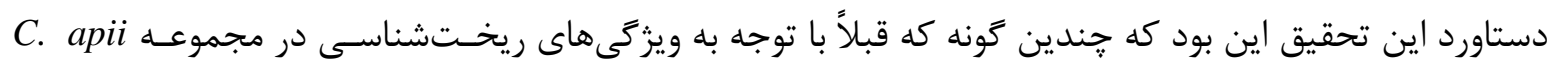
قرار مى گرفتند، گونههاى متمايزى هستند (Groenewald et al. 2013). علاوه براين مشخص شد برخى گونههـاى اين جنس تخصصيافتكى ميزبانى دارند و برخى داراى دامنه ميزبانى وسيع مىباشند؛ بنابراين، اين دادهــا نشـان دادند كه دادههاى ريختشناسى و تخصصيافتكى ميزبانى بهتنهايى براى تفكيك گونهاى جـنس Cercospora و توصيف كونههاى جديد كافى نيستند. در ضمن بر اساس اين دادهها مشخص شده است كـهـ بـا وجـود اينكـه ITS بهعنوان زن باركد عمومى در قارجها مطرح است، اما اين ناحيه نمىتواند پاسخكَوى تمايز بيشتر گونههاى قـارجى در جنس Cercospora باشد (Groenewald et al. 2013) و براى شناسايى و استنتاج فيلوزنتيكى كونههـاى ايسن جنس تركيبى از توالى ينج ناحيه زنى مذكور ضرورى مىباشد. 


\section{نتيجه كيرى و ييشنهاد}

از زمان توصيف و معرفى جنس Cercospora، آرايهبندى گونههاى آن دستخوش تغييـرات بسـيارى شـده

است. با توجه به فقدان ويزگگىهاى ريختشناسى مفيد و سطح بالاى تنوع درون گونهاى، رابطه ميزبانى، مـدتهـا بلعنوان ويزَگى عمده در تعيين حدود گونه در جنس Cercospora بهكار مىرفت. نتايج مطالعات بعدى نشـان داد كه رابطه ميزبانى بهعنوان يك معيار مناسب براى آرايهبندى گونههاى اين جنس مشكلساز مىباشــ، زيــرا تعـداد زيادى از گونهها داراى دامنه ميزبانى وسيع بوده و در عين حال روى يك ميزبان، گونههاى متعددى ممكـن اسـت ايجاد بيمارى كنند. در ضمن نتايج تحقيقات مولكـولى نيـز نشـان داده اسـت، ناحيـه ITS نمسى توانـد بـهتنهـايى ياسخكَوى تمايز بيشتر گونههاى قارجى در جنس Cercospora باشد؛ بنابراين به نظر مىرسد راهكار جنـدمنظرى يا به عبـارتى مفهـوم گونسه تركيبـى (Consolidated species concept) كـه بـهمنظـور رسيدن به نتيجه درست در مورد مرز گونهها، تمامى مفاهيم گَونه ريختشناسى، زيستشناسى و فيلوزنتيك را بـا ارزش ههى مختلف به كار مى گيرد (Quaedvlieg et al. 2014)، براى تفكيك گونههاى جــس Cercospora مفيــ است. بر اين اساس بيشنههاد مىشود كه در كشور ما نيز كه بيشتر كونههاى مطالعه شده از اين جنس بـر اسـاس خصوصيات ريختشناسى و رابطه ميزبانى تشخيص داده شداند، از نو جمع آورى، كشـت و بـا اسـتفاده از مفهـوم گونه تركيبى كه تركيبى از اطلاعات توالى DNA جندزنى، زيستشناسى، اكولوزى، رابطه ميزبـانى و ويزخى هـاى ريختشناسى را براى تعيين حدود كونهها به كار مى گيرد، مورد بازبينى قرار گيرند.

\section{References}

\section{منابع}

ا. بخشى م.، ارزنلو م. و باباى اهرى ا. اوسا الف. تعيين تيبهاى آميزشى قارج Cercospora beticola، عامل لكه بركى جغندرقند با استفاده از آغازگرهاى اختصاصى و امكان تشكيل مرحله جنسى آن در شرايط

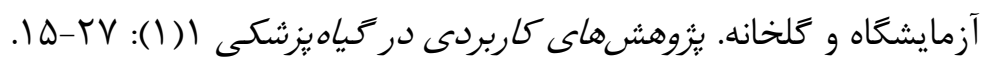

r. بخشى م.، ارزنلو م. و باباى اهرى ا. اوسا ب. توليد مثل جنسى و ساختار زنهاى تيب اميزشى در قارجهاى

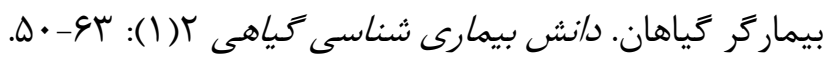


r. بخشى م.، ارزنلو م. و باباى اهرى ا. بوجا. شناسايى جدايهاى Cercospora beticola، عامل لكه بركى Cercospora

4. Arzanlou M., Abeln E.C., Kema G.H., Waalwijk C., Carlier J., Vries I.D., Guzmán M. and Crous P.W. 2007. Molecular diagnostics for the Sigatoka disease complex of banana. Phytopathology 97:1112-1118.

5. Bakhshi M., Arzanlou M. and Babai-Ahari A. 2011. Uneven distribution of mating type alleles in Iranian populations of Cercospora beticola, the causal agent of Cercospora leaf spot disease of sugar beet. Phytopathologia Mediterranea 50:101-109.

6. Bakhshi M., Arzanlou M. and Babai-Ahari A. 2012b. Morphological and molecular characterization of Cercospora zebrina from black bindweed in Iran. Plant Pathology and Quarantine 2:125-130.

7. Bolton M.D., Secor G.A., Rivera V., Weiland J.J., Rudolph K., Birla K., Rengifo J. and Campbell L.G. 2012. Evaluation of the potential for sexual reproduction in field populations of Cercospora beticola from USA. Fungal Biology 116:511-521.

8. Braun U., Nakashima C. and Crous P.W. 2013. Cercosporoid fungi (Mycosphaerellaceae) 1. species on other fungi, Pteridophyta and Gymnospermae. IMA Fungus 4:265-345.

9. Chupp C. 1954. A monograph of the fungus genus Cercospora. Ithaca, New York. 667p.

10.Coppin E., Debuchy R., Arnaise S. and Picard M. 1997. Mating types and sexual development in filamentous ascomycetes. Microbiology and Molecular Biology Reviews 61:411-428.

11.Crous P. W. and Braun U. 2003. Mycosphaerella and its anamorphs: 1. Names published in Cercospora and Passalora. CBS Biodiversity Series 1: 1-571.

12.Crous P. W. and Wingfield M.J. 1996. Species of Mycosphaerella and their anamorphs associated with leaf blotch disease of Eucalyptus in South Africa. Mycologia 441-458.

13.Crous P. W., Groenewald J.Z., Groenewald M., Caldwell P., Braun U. and Harrington T.C. 2006a. Species of Cercospora associated with grey leaf spot of maize. Studies in Mycology 55:189-197.

14.Crous P. W., Groenewald J. Z., Mansilla J. P., Hunter G. C. and Wingfield M. J. 2004. Phylogenetic reassessment of Mycosphaerella spp. and their anamorphs occurring on Eucalyptus. Studies in Mycology 50:195-214. 


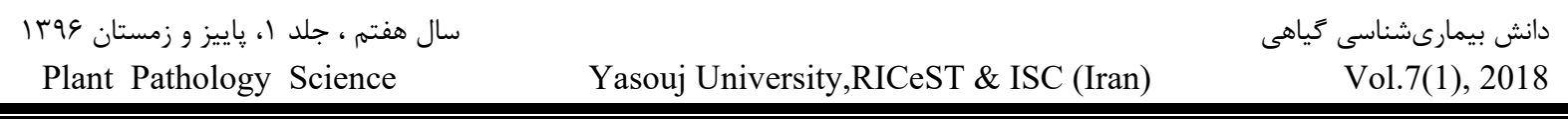

15.Crous P. W., Schoch C. L., Hyde K. D., Wood A. R., Gueidan C., de Hoog G. S. and Groenewald J. Z. 2009. Phylogenetic lineages in the Capnodiales. Studies in Mycology 64:1747.

16.Ellis M. B. 1971. Dematiaceous hyphomycetes. Kew, UK: Commonwealth Mycological Institute,

17.Fuckel K. W. 1863. Fungi Rhenani exsiccati, Fasc. I-IV. Hedwigia 2:132-136.

18.Groenewald J. Z., Groenewald M., Braun U. and Crous P. W. 2010. Cercospora Speciation And Host Range. Pp. 21-37. In: R. T. Lartey, J. Weiland, L. Panella, P. W. Crous, and C. Windels, (ed.). Cercospora Leaf Spot of Sugar Beet and Related Species. APS Press, Minnesota, USA.

19.Groenewald J. Z., Nakashima C., Nishikawa J., Shin H. D., Park J. H., Jama A. N., Groenewald M., Braun U. and Crous, P. W. 2013. Species concepts in Cercospora: spotting the weeds among the roses. Studies in Mycology 75:115-170.

20.Groenewald M., Groenewald J. Z. and Crous P. W. 2005. Distinct species exist within the Cercospora apii morphotype. Phytopathology 95:951-959.

21.Groenewald M., Groenewald J.Z., Braun U. and Crous P. W. 2006a. Host range of Cercospora apii and C. beticola and description of C. apiicola, a novel species from celery. Mycologia 98:275-285.

22.Groenewald M., Groenewald J. Z., Harrington T. C., Abeln E. C. and Crous P. W. 2006 b. Mating type gene analysis in apparently asexual Cercospora species is suggestive of cryptic sex. Fungal Genetics and Biology 43:813-825.

23.Hawksworth D. L., Crous P. W., Redhead S. A., Reynolds D. R., Samson R. A., Seifert K. A., Taylor J. W., Wingfield M. J., Abaci Ö. and Aime C. 2011. The Amsterdam declaration on fungal nomenclature. IMA Fungus 2:105-112.

24.Kimber R. B. E. and Paull J. G. 2011. Identification and genetics of resistance to cercospora leaf spot (Cercospora zonata) in faba bean (Vicia faba). Euphytica 177:419-429.

25.Kirk P. M., Stalpers J. A., Braun U., Crous P. W., Hansen K., Hawksworth D. L., Hyde K. D., Lücking R., Lumbsch T. H. and Rossman A. Y. 2013. A without-prejudice list of generic names of fungi for protection under the International Code of Nomenclature for algae, fungi, and plants. IMA Fungus 4:381-443.

26.Lartey R., Caesar-TonThat T., Caesar A., Shelver W., Sol N. and Bergman J. 2005. Safflower: A new host of Cercospora beticola. Plant Disease 89:797-801. 
27.Linde C. C., Zala M., Ceccarelli S. and McDonald B. A. 2003. Further evidence for sexual reproduction in Rhynchosporium secalis based on distribution and frequency of mating-type alleles. Fungal Genetics and Biology 40:115-125.

28.Moretti M., Saracchi M. and Farina G. 2004. Morphological, physiological and genetic diversity within a small population of Cercospora beticola Sacc. Annals of Microbiology 54:129-150.

29.Pollack F. G. 1987. An annotated compilation of Cercospora names. Mycological Memoirs $12: 1-212$.

30.Praveena R. and Naseema A. 2004. Fungi occurring on water hyacinth [Eichhornia crassipes (Mart.) Solms] in Kerala. Journal of Tropical Agriculture 42:21-23

31.Quaedvlieg W., Binder M., Groenewald J. Z., Summerell B. A., Carnegie A. J., Burgess T. I. and Crous P. W. 2014. Introducing the Consolidated Species Concept to resolve species in the Teratosphaeriaceae. Persoonia 33:1-40.

32. Silva M. and Pereira O. L. 2008. Postharvest Cercospora apii fruit rot disease on Cucurbita maxima (Cucurbitaceae). Australasian Plant Disease Notes 3:21-23.

33.Tessmann D.J., Charudattan R., Kistler H.C. and Rosskopf E.N. 2001. A molecular characterization of Cercospora species pathogenic to water hyacinth and emendation of $C$. piaropi. Mycologia 93: 323-334.

34.Weiland J., Eide J., Rivera-Varas V. and Secor G. 2001. Genetic diversity of Cercospora beticola in the US and association of molecular markers with tolerance to the fungicide triphenytlin hydroxide. Phytopathology 91: 94. 